Revista Bioética

\title{
PESQUISA
}

\section{A case study of social vulnerability: thoughts for the promotion of health}

Lucas França Garcia ${ }^{1}$, Marcelo Picinin Bernuci ${ }^{1}$, Andrea Grano Marques ${ }^{1}$, Sonia Maria Marques Bertolini ${ }^{1}$, Tania Maria Gomes da Silva ${ }^{1}$

1. Programa de Pós-Graduação em Promoção da Saúde, Pró-Reitoria de Pesquisa, Pós-Graduação e Extensão, Centro Universitário de Maringá (UniCesumar), Maringá/PR, Brasil.

\begin{abstract}
Health promotion is a set of strategies that aim to improve the quality of life of individuals and populations. Since these strategies are based on social determinants of health, it is important to identify vulnerability issues in order to explore their impact on health care. The present study describes a case study showing the perception of women on poverty as violence and social vulnerability and the impact of the same on health. A qualitative study was performed, based on content analysis. The results are presented in narrative form and address: 1) poverty as social vulnerability; 2 ) poverty and perceptions of violence; 3 ) poverty and associated health outcomes. We found that poverty was a central question of social vulnerability which can be a determinant for women's lives. It is therefore important to consider subjectivities regarding violence and social vulnerability on populations living in poverty when designing health promotion policies.

Keywords: Health promotion. Social vulnerability. Poverty. Violence. Public policy.
\end{abstract}

\section{Resumo}

Um estudo de caso sobre vulnerabilidade social: reflexões para a promoção da saúde

A promoção da saúde é um conjunto de estratégias que visam melhorar a qualidade de vida de indivíduos e populações. Como suas estratégias estão baseadas nos determinantes sociais da saúde, é importante identificar as questões de vulnerabilidade social e seu impacto na assistência à saúde. Este é um estudo de caso sobre a percepção da mulher acerca da pobreza como violência e vulnerabilidade social e o seu impacto na saúde. Estudo qualitativo foi realizado, utilizando análise de conteúdo. Os resultados são apresentados em forma narrativa: 1) a pobreza como vulnerabilidade social; 2) pobreza e percepções de violência; 3) pobreza e desfechos de saúde associados. Conclui-se que a pobreza é uma questão central de vulnerabilidade social que pode ser determinante para a vida das mulheres. Assim, é importante considerar as subjetividades relacionadas à violência e à vulnerabilidade social de populações em situação de pobreza no desenho das políticas de promoção da saúde.

Palavras-chave: Promoção da saúde. Vulnerabilidade social. Pobreza. Violência. Política pública.

\section{Resumen}

\section{Un estudio de caso sobre vulnerabilidad social: reflexiones para la promoción de la salud}

La promoción de la salud es un conjunto de estrategias que apuntan a mejorar la calidad de vida de personas y poblaciones. Dado que estas se basan en determinantes sociales de la salud, es importante identificar los problemas de vulnerabilidad para explorar su impacto en la salud. El presente trabajo describe un estudio de caso que muestra la percepción de las mujeres sobre la pobreza como violencia y vulnerabilidad social y su impacto en la salud. Se realizó un estudio cualitativo, basado en el análisis de contenido. Los resultados se presentan en forma narrativa: 1) pobreza como vulnerabilidad social; 2) pobreza y percepciones de violencia; 3) pobreza y efectos en la salud asociados. Señalamos la pobreza como un problema central de vulnerabilidad social que puede ser determinante para la vida de las mujeres. Por lo tanto, en el diseño de políticas de promoción de la salud es importante considerar las subjetividades relacionadas con violencia y vulnerabilidad social en poblaciones que viven en la pobreza.

Palabras clave: Promoción de la salud. Vulnerabilidad social. Pobreza. Violencia. Política pública. 
Health promotion are strategies to produce health, in the individual and collective sphere, characterized by articulation and cooperation through a Health Care System ${ }^{1}$. As discussed at the 22nd World Conference on Health Promotion in Curitiba in 2016, strengthening health promotion and ensuring greater equity in access to health services can improve people's quality of life. The document published at this conference, known as the Curitiba Letter, emphasized that equity is a requirement for health and had been an essential objective of health promotion for at least three decades ${ }^{2}$.

The concept of health promotion recognizes existing policies and technologies, and seeks equity and the quality of life (QoL) of individuals, with processes to reduce vulnerability and risk derived from the social determinants of health ${ }^{3}$. The World Health Organization (WHO) conceptualizes QoL as the perception of the individual of his position in life, in the context of the culture and value system in which he lives and in relation to his objectives, expectations, patterns and concerns ${ }^{4}$. When proposing policies for health promotion, therefore, the analysis and knowledge of the physical, psychological, social and environmental dimensions of the individual are required to guarantee proper conditions for health care.

In 2000, the United Nations (UN) presented its Millennium Development Goals (MDGs) as an important step towards improving the health of the global population, recognizing that poverty, health and development are closely intertwined and must be tackled together in any actions aimed at improving QoL ${ }^{5}$. In the same way, the 2030 Agenda for Sustainable Development recognizes the challenge of integrating economic, social and environmental objectives into a unified action plan for people, the planet and prosperity ${ }^{6}$. In developing countries such as Brazil, these challenges are currently even greater, as the persistence of severe poverty represents threatening consequences for sustainable development. Despite the efforts of the MDGs, such as increased investment in infrastructure, the prospect of achieving an explicit impact on reducing poverty in Brazil still remains utopian and distant ${ }^{7}$.

Poverty and violence are defined as processes of vulnerability, or conditions inherent to individual will, leaving individuals exposed to exploitation and coercion. Health policies, especially for the promotion of health, are important tools for confronting vulnerability ${ }^{8}$. To create effective public policies, studies that seek to obtain information that considers the subjectivity of the relationship between the subject, the health-disease process and the social determinants of health are essential. This article therefore explored the issues related to poverty as a form of social vulnerability and its impacts on health care and the importance of health promotion in public policies that aim to reduce poverty.

\section{Method}

This is a qualitative-descriptive study. Data was collected through oral histories. This method uses oral sources, such as interviews, for the collection of testimonies. For Portelli ${ }^{9}$, oral history is primarily the art of listening and is based on a set of relationships, such as the dialogue between the interviewer and interviewee; the relationship between the moment when the dialogue occurs and the moment recalled; the relationship between the public and private sphere; between autobiography and history or between history and stories, and, finally, the relationship between the oral source oral and the writing of the historian.

The interviews were conducted by a historian (TG) at the interviewee's home in September and November 2017. Interviews were transcribed verbatim and analyzed by a historian (TGS), a sociologist (LFG) and a psychologist (AGM). Two researchers, both trained in Social and Human Sciences (LFG and TG), developed the coding model.

Bardin's ${ }^{10}$ thematic content analysis was used to analyze the data. Three stages of content analysis were observed (pre-analysis, exploration of material and interpretation of results). The coding scheme was developed to allow units of meaning to emerge from the text. The data were analyzed with Nvivo 11 for Windows. The personal data of the interviewee, such as city of residence and real name, were omitted, in order to maintain research participant privacy. The fictitious name Eni was used.

\section{Results}

Eni is a 71-year-old brown-skinned woman who has experienced difficult life-long experiences because of poverty, illiteracy and her status as a woman in a society marked by patriarchy. She lives in a simple house in one of the poorest neighborhoods of the city. The mother of seven children, she has 19 grandchildren and 5 great-grandchildren. She has 
had two long-term relationships in her life, namely non-formalized cohabitation, but had various relations with men during the period when, she is not afraid to admit, she was a prostitute. While her life is less difficult today, there was a time when she and her children went hungry and she was forced to beg for food.

The life of Eni was and still is marked by the daily tackling of diverse social, economic and health problems related to processes of social vulnerability. Poverty, violence, the loss of a husbands, whether by death or abandonment, the death of her son, the imprisonment of her peers and children, beginning work very early in life and changes of address are some of the problems associated with social vulnerability Eni has experienced throughout her life. Today she lives in the northwestern region of Paraná with her son and daughter-in-law and represents a remarkable history of resilience, due to the great difficulties she has faced since very early on in life.

The main themes that emerged from the collected material, identified through thematic content analysis, were poverty, health outcomes associated with poverty and perceptions of and about violence, with special focus on gender and vulnerability.

\section{Poverty as social vulnerability}

Poverty emerges as one of the main themes in Eni's discourse. A shortage of food for herself and her children are constant stories, although she states that she has always strived to ensure that there is no lack of food for her children and grandchildren. Great suffering has accompanied her from an early age, and has endured throughout her life in the raising of her children, demonstrating the social reproduction of poverty and social inequalities. Eni says that she started working very early, at the age of 12 , in various types of jobs - domestic labor, general services, cane extraction, coffee harvesting. Several of these tasks required a lot of physical effort, such as working in sugar cane and coffee extraction. These are some important examples for understanding the processes of vulnerability to which Eni has been susceptible throughout his life:

"Suffered, I suffered a lot in my life. I suffered, I suffered, I was hungry, do you understand?" (e2);

"And there was poverty. I was very poor. I begged, it wasn't enough. We used to earn money in the fields. I worked a lot in the countryside, I worked with sugar cane, with coffee, I worked in cotton picking, but it didn't work. I suffered a lot, I was very hungry" (e3);

"I started working when I was 12 years old. I worked as a domestic worker, as a carer, then I went to work with Mr. X. I worked for 3 years in Mr. X's hospital. Always working. I worked with sugar cane, I worked in the Cooperative. When I wasn't at the cooperative I was at company $Y$, at night, always working, now I've stopped working" (e1).

The suffering associated with this lack of material resources, due to the low earnings associated with her labor activity, or unemployment, is also present in Eni's speech. Sometimes, she describes the psychological suffering she underwent when her children asked for things she knew she could not provide as she did not have the means to meet these demands, a feeling that was also identified as a form of violence, as is shown below:

"The most difficult thing in my life was that I had to work hard, I worked as a slave to take care of the children ... it really hurt me" (e1);

"It was the greatest sadness of my life to see my children ask for things and not be able to give them to them... That, when children ask for things and which we do not have, is suffering" (e3).

\section{Poverty and perceptions of violence}

The perception of violence is another important issue that emerges through the analysis of Eni's discourse. Although she says she has never suffered any type of violence, it is important to emphasize that violence, for Eni, is understood as only that which causes physical harm to the individual. She frequently cites physical harm as an example of violence, as she described this type of violence in places where she lived and worked, and even within her family:

"There is the person who beats us, right? A man who mistreats us, who beats us, hurts us, no, I've never [suffered from this]" (e1)

"That never happened to you?" (TG)

“No" (e1) 
Although subtle forms of exploitation and social coercion such as symbolic violence were not recognized by Eni as part of her life, they are present in her dialogue, even if they are not cited as violence. Eni recognized poverty as violence, insofar as this was an important source of producing suffering to her. Abandonment by her partners, for various reasons, the imprisonment of her partners and children, are other examples of symbolic violence that Eni has been subjected to all these years.

"Poverty to me is violence because we fight, we fight, we fight and we never get there (...) You know? (...) We fight, we fight, we never reach it, it's difficult to reach it, you know?" (e3);

"He [her partner] made me suffer a lot. He hid food from me. I am with him because I feel sorry for him, no, but I do not love him, I do not love him. He did the shopping and you know what he did? He had a box and he hid the children's food in that box" (e1).

Symbolic violence also appears when she recounts an important event in her life, which was the attempt by Child Welfare Services to take her children and grandchildren away due to their social conditions. The custody of her grandson, although it was subsequently reversed, is seen, although not directly, as a form of symbolic-institutional violence on the part of the government:

"They said that we couldn't look after them (...) For God sake, she could not take my children away, you know, she said my daughter wasn't able to take care of her son: 'Better give him up, you are not able to take care of him'" (e1).

\section{Poverty and associated health outcomes}

This condition of poverty, associated with a history of significant losses in her life, ended up having a direct impact on Eni's health outcomes. Alcoholism and tuberculosis are two important health problems associated with vulnerability. The first, appears in the context of a major loss in her life - the moment when her first partner abandoned her. The diagnosis of tuberculosis occurred when she worked in a hospital and became ill. After this episode, she was treated by the Institution and was diagnosed, which she believes was related to her alcoholism and lifestyle at the time. Loss is also an important part of Eni's speech and an important part of understanding the context of social vulnerability in which she finds herself and the impact on her health, which is understood as a biopsychosocial process:

"Ah, it was a shock because I loved him so much [her first partner who left her]. From that day on I started drinking, then my life ended, I started drinking" (e1);

"Oh, what most scarred my life was the death of my son, my son... What I suffered the most was the pain in the heart of losing him" (e1);

"From drinking too much [she developed tuberculosis], going out to parties. (...) When I had lung problems, I was working in Hospital X. It was still Hospital $Y$. They [doctors] told me like this: 'I'm going to hospitalize you'" (e1).

The isolation and stigma associated with tuberculosis are also issues of the health-diseasecare process reported by Eni, derived from this process of social vulnerability caused by poverty. Avoidance by others and contempt are some of the feelings reported by Eni arising from the stigma associated with tuberculosis:

"There I was hospitalized [for the treatment of tuberculosis], after that I didn't go to anyone's house, because if I went to someone's house and drank anything they'd wash the glass, or threw it away" (e1);

"Oh, I felt terrified, angry... Oh Lord, they were getting rid of $m e$ " (e1).

\section{Discussion}

The National Health Promotion Policy (PNPS) is divided into seven priority action themes. One of its objectives is Contribute to the adoption of social and health practices focused on equity, participation and social control, in order to reduce systematic inequalities, unjust and avoidable, respecting differences in social class, gender, sexual orientation and gender identity, between generations, ethnic and racial, cultural, territorial, and related to people with disabilities and special needs ${ }^{3}$.

In this context, one of the priority issues, the promotion of the culture of peace and human rights, has as one of its action areas the vulnerability and health of women and gender issues. As we can see in Eni's story, social vulnerability, in its different forms, such as poverty and violence, is clearly present. 
Vulnerability is a concept with many meanings from the point of view of the Human Sciences ${ }^{8,11}$ and is the main theme to emerge from Eni's discourse, to the extent that her life was affected by various situations of social and psychological vulnerability. Vulnerability can be defined as dynamic, that is, a temporary situation in which the individual is subject to coercion or exploitation due to their susceptibilities, or static, that is, when a condition inherent to the individual's will subjects them to permanent exposure to processes of coercion and exploitation ${ }^{8,12}$.

An example of the first type of vulnerability is related to certain health-disease-care processes, when the individual suffers the temporary deprivation of their decision-making capacity. An example of static vulnerability is disability, as it is a condition inherent to the human will, which leaves the individual susceptible to processes of exploitation and social coercion ${ }^{8,12}$. However, there are certain situations and conditions that can be framed in both types of vulnerability ${ }^{13}$, such as poverty and violence, both of which are present in Eni's speech in a highly explicit manner.

Vulnerability is an important point in Eni's life story and has been frequently discussed in recent decades, whether in the academic field, or by management councils and implementers of social policies. It is therefore not exactly a new term, as it was already used in the legal area, in which it is associated with the defense of human rights, as well as in an environmental context, in relation to the physical and biotic characteristics of the environment. However, the last two decades have seen the strengthening of the concept of vulnerability, complementing the already consolidated expressions.

In the economic sphere, due to the exhaustion of Marxist paradigms, vulnerability overlaps with the expression "poverty", which specifically refers to the absence of material resources, including those excluded from the right of citizenship ${ }^{14}$. In other words, vulnerability becomes more broadly understood from the social point of view. In the area of health, it emerged in association with the AIDS epidemic, in the 1990s, with male homosexuals making up the so-called group that was vulnerable to the disease and, in a certain manner, placing itself as an alternative to the concept of risk, closer to the epidemiological area ${ }^{15}$.

Although vulnerability should not be related solely to social class, as new studies require, it is well known that the population with the lowest incomes makes up the most fragile group ${ }^{16}$. Studies in Latin America highlight that women represent the most vulnerable segment of the population, highlighting the phenomenon known as the feminization of poverty ${ }^{14}$. However, this an analysis presents complexities, as Costa and Marguti ${ }^{17}$ have shown that based on Brazilian indicators between 1983 and 2003, there is no evidence of any kind of pattern that justifies talk of the feminization of poverty. There is evidence of fragility in family structures without specific compartmentalization by gender. In Brazil, the issue of vulnerability imposed by poverty thus has roots in its socioeconomic and economic formation, affecting men and women without distinction by gender ${ }^{18}$. In the area of health too, men exhibit worse conditions than women; as demonstrated by the lower survival rates among the male gender ${ }^{19}$. It is important to note that higher mortality in men, especially in the 20-25 year age group, may be explained by the rates of structural violence in Brazil, such as the drug trade, traffic accidents and others ${ }^{20}$. It must be admitted, however, that gender, class and race or ethnicity presently make up the critical structure of bioethical theories for the understanding of all forms of oppression and vulnerability of individuals ${ }^{20}$. In this way, health promotion, the alleviation of poverty and advances in economic development will only occur when women are seen as totally human and are equally valued as people and in health ${ }^{21}$

The history of Eni, although highly individual, is the history of many Brazilians and people living in developing countries. According to a report World Bank report, after a period when poverty was expressively reduced between 2004 and 2014, there is currently a trend of increasing poverty in Brazil. According to this report, an increase of between 2.5 and 3.6 million people living in poverty is estimated. The report still highlights that the increase in poverty between 2015 and 2016 varies in urban and rural areas, with different dynamics in each of the scenarios ${ }^{22}$.

Economic austerity policies have been identified as one of the main causes of the current trend of increasing poverty ${ }^{23,24}$. It is important to highlight that the poverty criterion of the World Bank is based on a quantitative cut-off point, which does not consider other social aspects, such as the presence of violence, the lack of basic sanitation, and other important aspects of social and human development. 
This dynamic of poverty derived from urbanization processes and the rural exodus in Brazil was studied by Milton Santos ${ }^{25,26}$. He says that the processes of globalization accelerated the process of urbanization without the rationality associated with this process. The result of this "unplanned" urbanization is that many people and families who previously lived in rural centers were forced to move to urban regions, with less material and symbolic resources, and mostly in situations of poverty ${ }^{25-28}$.

Another important aspect of poverty as a social vulnerability is the issue of violence, especially against women, in its different forms, from physical to psychological. According to the latest "Map of Violence", published in 2015, the most frequent types of violence suffered by women are physical, psychological, sexual violence and neglect/abandonment, respectively, with older women being the most vulnerable group ${ }^{29}$. An important aspect of violence against women, especially concerning Eni's discourse, is what Pierre Bourdieu calls symbolic violence ${ }^{30}$.

Symbolic violence is that which generates harm in the individual, without, necessarily, the presence of associated physical coercion ${ }^{30}$. Moral, psychological, institutional violence, are examples of this and are present in the discourse of Eni. and in a certain manner are also part of the types of violence present in cycles of the reproduction of social inequalities ${ }^{31}$, which must be the subject of public policies for the reduction of poverty and violence. The moral and psychological damage caused or resulting from the insults of a partner or the actions of state apparatuses, considered legal (from the perspective of legal legitimacy) such as the threat, direct or indirect, to withdraw custody of children, are important examples of symbolic, psychological and institutional violence. Neglect or abandonment, as indicated by the "Map of violence", as well as the direct or indirect threat of withdrawing the custody of children and grandchildren are some of the examples of symbolic violence present in Eni's discourse.

The relationship between social vulnerabilities, especially poverty, and health outcomes is an important public health issue. Several studies have shown that people living in situations of poverty and violence have important health problems such as atypical brain development, leading to cognitive problems that have a direct impact on learning processes ${ }^{32}$, a high occurrence of mental health problems, which are three times higher in people living on the poverty line than in people with low incomes ${ }^{33}$; infections and $\mathrm{STD}^{34}$, and chronic diseases ${ }^{35}$. The fact that Eni has constantly lived in conditions of social vulnerability has exposed her to different health outcomes. Alcoholism, tuberculosis and chronic health problems, such as hypertension, are examples of the clinical outcomes that may be related to the social vulnerability in which Eni has lived.

\section{Final considerations}

Eni's story reveals the importance of considering poverty as one of the main forms of vulnerability in developing countries such as Brazil. We can therefore conclude that there is a need to create more effective public policies to combat poverty and violence, which consider the subjective conditions of people, their intersubjectivity, their material and symbolic conditions and the environment in which they live. The valuation of subjectivity and the relationship between the subject, the health-disease process and the social determinants of health are important aspects to be considered in the creation of public health promotion policies aimed at the reduction of poverty and violence and the improvement of the quality of life and well-being of people living in situations of vulnerability.

We are grateful for the Research Scholarship from the Iceti/UniCesumar - Instituto Cesumar de Ciência, Tecnologia e Inovação (Iceti UniCesumar - Institute of Science, Technology and Innovation), and the Coordenação de Aperfeiçoamento de Pessoal de Nível Superior (Capes Foundation).

\section{Referências}

1. Brasil. Ministério da Saúde. As cartas da promoção da saúde [Internet]. Brasília: Ministério da Saúde; 2002 [acesso 8 dez 2017]. Disponível: https://bit.ly/22uqOY4

2. Associação Brasileira de Saúde Coletiva. Carta de Curitiba sobre promoção da saúde e equidade [Internet]. 23 ago 2016 [acesso 8 dez 2017]. Disponível: https://bit.ly/2Z1pgZa 
3. Brasil. Ministério da Saúde. Política nacional de promoção da saúde: revisão da Portaria MS/GM no 687, de 30 de março de 2006 [Internet]. Brasília: Ministério da Saúde; 2014 [acesso 8 dez 2017]. Disponível: https://bit.ly/2wGfLR3

4. The World Health Organization Quality of Life assessment (WHOQOL): position paper from the World Health Organization. Soc Sci Med [Internet]. 1995 [acesso 8 dez 2017];41(10):1403-9. p. 1405. Disponível: https://bit.ly/2YYRowd

5. United Nations. United Nations millennium development goals [Internet]. New York: United Nations; 2000 [acesso 8 dez 2017]. Disponível: https://bit.ly/1a1Rery

6. United Nations. Resolution adopted by the General Assembly on 25 September 2015: Transforming our world: the 2030 Agenda for Sustainable Development [Internet]. New York: United Nations; 2015 [acesso 8 dez 2017]. Disponível: https://bit.ly/33yxWKf

7. Marinho E, Campelo G, França J, Araujo J. Impact of infrastructure expenses in strategic sectors for Brazilian poverty. EconomiA [Internet]. 2017 [acesso 8 dez 2017];18(2):244-59. Disponível: https://bit.ly/2YMHna3

8. Ten Have H. Vulnerability: challenging bioethics. New York: Routledge; 2016.

9. Portelli A. História oral como arte da escuta. São Paulo: Letra e Voz; 2016.

10. Bardin L. Análise de conteúdo. São Paulo: Edições 70; 2011.

11. Kottow MH. The vulnerable and the susceptible. Bioethics [Internet]. 2003 [acesso 8 dez 2017];17(5-6):460-71. Disponível: https://bit.ly/2TEnRqF

12. Hawkins JS, Emanuel EJ, editores. Exploitation and developing countries: the ethics of clinical research [Internet]. New Jersey: Princeton University Press; 2008 [acesso 8 dez 2017]. Disponível: https://bit.ly/301iVhV

13. Bajotto AP, França Garcia L, Goldim JR. What is vulnerability? A qualitative study about the perception of vulnerability in adults and older adults. J Clin Res Bioeth [Internet]. 2017 [acesso 8 dez 2017];8(2):1000299. Disponível: https://bit.ly/31B5oxO

14. Monteiro SRRP. O marco conceitual da vulnerabilidade social. Soc Debate [Internet]. 2011 [acesso 8 dez 2017];17(2):29-40. Disponível: https://bit.ly/33vtV9f

15. Oviedo RAM, Czeresnia D. O conceito de vulnerabilidade e seu caráter biossocial. Interface Comun Saúde Educ [Internet]. 2015 [acesso 8 dez 2017];19(53):237-49. Disponível: https://bit.ly/2Z22SD9

16. Schramm FR, Kottow M. Principios bioéticos en salud pública: limitaciones y propuestas. Cad Saúde Pública [Internet]. 2001 [acesso 8 dez 2017];17(4):949-56. Disponível: https://bit.ly/2ctX1j7

17. Costa MA, Marguti BO, editores. Atlas da vulnerabilidade social nas regiões metropolitanas brasileiras [Internet]. Brasília: Instituto de Pesquisa Econômica Aplicada; 2015 [acesso 8 dez 2017]. Disponível: https://bit.ly/2ZZrMjT

18. Silva MOS. Pobreza, desigualdade e políticas públicas: caracterizando e problematizando a realidade brasileira. Rev Katálysis [Internet]. 2010 [acesso 8 dez 2017];13(2):155-63. Disponível: https://bit.ly/2TuhPZw

19. Bidinotto DNPB, Simonetti JP, Bocchi SCM. Men's health: non-communicable chronic diseases and social vulnerability. Rev Latinoam Enferm [Internet]. 2016 [acesso 8 dez 2017];24:e2756. Disponível: https://bit.ly/2KOcbgl

20. Diniz D, Guilhem D. Feminismo, bioética e vulnerabilidade. Estud Fem [Internet]. 2000 [acesso 8 dez 2017];8(1):237-44. Disponível: https://bit.ly/2yVeEjV

21. Thompson JE. Poverty, development and women: why should we care? J Obstet Gynecol Neonata Nurs [Internet]. 2007 [acesso 8 dez 2017];36(6):523-30. Disponível: https://bit.ly/2N2eeQZ

22. Skoufias E, Nakamura S, Gukovas RM. Salvaguardas contra a reversão dos ganhos sociais durante a crise econômica no Brasil [Internet]. Washington: World Bank Group; 2017 [acesso 8 dez 2017] Disponível: https://bit.ly/2NDeCIV

23. Garcia LP. A economia desumana: porque mata a austeridade [resenha]. Cad Saúde Pública [Internet]. 2016 [acesso 8 dez 2017];32(11):e00151116. Disponível: https://bit.ly/30cGV1H

24. Doniec K, Dall'Alba R, King L. Austerity threatens universal health coverage in Brazil. Lancet [Internet]. 2016 [acesso 8 dez 2017];388(10047):867-8. Disponivel: https://bit.ly/2N01nyX

25. Santos M. A urbanização desigual: a especificidade do fenômeno urbano em países subdesenvolvidos. Petrópolis: Vozes; 1980.

26. Santos M. A pobreza humana. São Paulo: Hucitec; 1979.

27. Hunter P. More science in urban development. EMBO Rep [Internet]. 2017 [acesso 8 dez 2017];18(2):201-4. Disponível: https://bit.ly/31zVU5P

28. Liddle B. Urbanization and inequality/poverty. Urban Sci [Internet]. 2017 [acesso 8 dez 2017];1(4):35. Disponível: https://bit.ly/2Z4T86U

29. Waiselfisz JJ. Mapa da violência 2015: homicídio de mulheres no Brasil [Internet]. Brasília: Flacso Brasil; 2015 [acesso 8 dez 2017]. Disponível: https://bit.ly/2LixlmB

30. Bourdieu P. O poder simbólico. São Paulo: Difel; 1989.

31. Bourdieu P, Passeron JC. A reprodução: elementos para uma teoria do sistema de ensino. Petrópolis: Vozes; 2008.

32. Hair NL, Hanson JL, Wolfe BL, Pollak SD. Association of child poverty, brain development, and academic achievement. Jama Pediatr [Internet]. 2015 [acesso 8 dez 2017];169(9):822-9. Disponível: https://bit.ly/2Z4TwCo

33. Hudson CG. Socioeconomic status and mental illness: tests of the social causation and selection hypotheses. Am J Orthopsychiatry [Internet]. 2005 [acesso 8 dez 2017];75(1):3-18. Disponível: https://bit.ly/2Mnpx79 
34. Mena L, Crosby RA, Geter A. A novel measure of poverty and its association with elevated sexual risk behavior among young Black MSM. Int J STD Aids [Internet]. 2017 [acesso $8 \mathrm{dez}$ 2017];28(6):602-7. Disponível: https://bit.ly/2Mh2Zor

35. Tung EL, Cagney KA, Peek ME, Chin MH. Spatial context and health inequity: reconfiguring race, place, and poverty. J Urban Health [Internet]. 2017 [acesso 8 dez 2017];94(6):757-63. Disponível: https://bit.ly/2TsxRTJ

Participation of the authors

All the authors contributed to the planning of the study, data analysis, the writing of the text and the critical review of the manuscript.

\section{Correspondência}

Lucas França Garcia - Centro Universitário de Maringá. Programa de Pós-Graduação em Promoção da Saúde Av. Guedner, 1.610, Jardim Aclimação CEP 87050-390. Maringá/PR, Brasil.

Lucas França Garcia - Doutor - lucasfgarcia@gmail.com

(iD) 0000-0002-5815-6150

Marcelo Picinin Bernuci - Doutor - marcelo.bernuci@unicesumar.edu.br

(iD) 0000-0003-2201-5978

Andrea Grano Marques - Doutora - andrea.marques@unicesumar.edu.br (iD) 0000-0001-6863-4809

Sonia Maria Marques Bertolini - Doutora - sonia.bertolini@unicesumar.edu.br (iD) 0000-0001-6587-5041

Tania Maria Gomes da Silva - Doutora - tania.gomes@unicesumar.edu.br (iD) $0000-0002-5495-9968$ 


\section{Annex}

\section{Semi structured interview}

a) What is your full name?

b) How old are you?

c) What is your education level?

d) What is your household income, how much are you earning today? Do you get a retirement pension?

e) How many children did you have? And grandchildren? Do you have any great-grandchildren? Has the relationship with your children always been good?

f) I would like you to tell me about your life, what you remember, what was most important, what most impacted you. You can talk freely.

g) Let's go back a while, I mean, not a little while, let's go back to your childhood. What do you remember about your childhood?

h) How old were you when you started working? Where did you work?

i) How old were you when you got married? How did the relationship end? What is your life like? How is your relationship with him? Let's talk about your relationship with this first companion. Was he good to you?

j) How is your health today? Do you take any medicine? What for?

k) Now, what about male violence against you? If you were to talk about the worst violence you have ever suffered, who would you say perpetrated violence against you? What do you think is violence?

I) Do you know what male chauvinism is? Do you think you've had macho men in your life? Do you know many male chauvinistic men?

m) So for you, are violent men those who beat women?

n) Would you like to add some moment in your life or something else that we did not talk about during these interviews? 